\title{
Article
}

\section{Paradox of Limited Water Resources in Iran and Goals of Self-Sufficiency in Agricultural Sector}

\author{
Hamed Rafiee ${ }^{1, *}$ and Fereshteh Balovi ${ }^{2}$ \\ ${ }^{1}$ Assistant Professor, Department of Agricultural Economics, University of Tehran, Iran; hamedrafiee@ut.ac.ir \\ ${ }^{2} \mathrm{MA}$ in Irrigation and Drainage, Faculty of Water Engineering, Shiraz University, Iran; \\ Fereshteh.balovi@gmail.com \\ * Correspondence: hamedrafiee@ut.ac.ir; Tel.: 00982632247783
}

\begin{abstract}
Lack of water resources in Iran, especially in recent years, has faced the agricultural sector as the most important consumer of water resources, with serious challenges. In Iran, the agricultural sector accounted for more than $90 \%$ of water consumption. However, the focus on domestic production and self-sufficiency policy in staples (wheat, barley, maize and rice) has been emphasized in general agriculture's policy. This study was conducted to estimate the imported virtual water from the imports of basic products in Iran using defined indicators during 1961-2013. Also this study investigated the possibility of achieving self-sufficiency due to the limited water resources in Iran. The results of this study showed with the increase in cereal imports, virtual water imports from 0.28 billion cubic meters in 1961 increased to 17.6 billion cubic meters in 2013 and on average about $60 \%$ of virtual water imports in strategic products is related to wheat imports during the past 53 years. Other products in cereal (barley, maize and rice) are also indicative of the general trend of increasing imports of virtual water in development plans. The estimated long-run elasticity of virtual water imports in the cereal group compared with the country's water resources also showed that with a one percent reduction in renewable water resources of the country, the virtual water import in the main cereal group will increase equivalent to 2.89 percent and the determination coefficient more than 90 percent also confirms this negative relationship. According to this result and the emphasis on the fact that renewable water resources per capita in the country is falling increasingly, it cannot be expected that domestic production could compensate for the imports of the cereal group and virtual water imports with current technology, without increasing the water productivity and without additional harm to water resources.
\end{abstract}

Keywords: Virtual water; Agriculture; Staples; Water resources per capita

\section{Introduction}

With shortage of freshwater resources in the world, a topic which has been of concern about the impact of trade different products on the use of water resources in recent years, was water trading that is referred to as virtual water trade (VW) [1, 22]. By definition, virtual water is the amount of water a commodity or a product of agricultural uses in the production process to reach the stage of development and its value is equal to the total water used in the different stages of the production chain from start to finish $[1,6]$. In this definition, virtual attribute implies that most of the water consumed in the production process does not have a physical presence in the final product and in fact, at the end, a tiny fraction of the water used will be remained as real water in product texture. The important thing is that the virtual attribute is not meant to be unreal. It should be stated explicitly that virtual water is quite real water [2]. Virtual water trade is an essential tool and standard in calculating national actual water use. During the last 40 years, trade in virtual water has been rising steadily. In fact, 67 percent of world trade in virtual water is associated with global trade in crops and 23 percent of livestock products and related products and only 10 per cent belongs to industrial production [6]. Due to worsening water crisis in many countries, the issue of virtual water trade in 
planning and trade policy-making in agricultural products is of great importance, especially in countries with arid and semi-arid conditions $[2,11]$. Paradoxically, Iran's structure in the agricultural sector is that, the country is faced with limited water resources and the agriculture sector is accused mainly for the indiscriminate use of water resources with the current products on the one hand and in the second paragraph of agricultural policies issued in the year 2011, "Food security by relying on internal resources and attaining self-sufficiency in the production of basic products" were emphasized on the other hand. In fact, self-sufficiency does not mean dependence on imports and the goal is supply the country's domestic need by domestic production. However, one must consider that in the current situation, achieving the self-sufficiency would be realistic to what extent. The studies conducted in Iran were mainly regional and large studies such as those that have been investigated in the present study have no much history. On a global scale, the results by Fraiture et al. (2004) showed that in 1995, the sum of all imports included 215 million tons of cereal, which in the case of lack of cereal imports, importing countries were forced to spend 433 cubic kilometers of their effective precipitation (rainfall plus irrigation) and 178 cubic kilometers of irrigation water from local water sources [5]. The study by Chapagain, et al. (2005) showed that the total amount of water required in importing countries was $1605 \mathrm{Gm} \mathrm{y}^{-1}$, if all imported agricultural products were produced inside the country. In the exporting countries, however these products are produced only with 1253 $\mathrm{Gm} \mathrm{y}^{-1}$ which make saving of $352 \mathrm{Gm} \mathrm{y}^{-1}$ of water [3]. Silva et al. (2016) in a study in Brazil, have determined national water footprint of food consumption in Brazil, linking the virtual water trade in goods with the main agricultural, water shortages, water sufficiency and dependence of water in each region of Brazil. Their results showed that the average water footprint of food consumption in Brazil was $1619 \mathrm{M}^{3}$ per year per person [9]. In a study by Serrano et al. (2016), it demonstrated that the total per capita water footprint was $2.280 \mathrm{~m}^{3}$ for EU consisting mainly of green water that has been removed in conventional calculations of water. The use of blue and gray water in the European water policy only includes $32 \%$ of the total water footprint. They have also found that Europeans accounted for 585 cubic kilometers of virtual water or about 28 percent of global virtual water trade flow in 2009 [8].

Due to the limited water resources in Iran and Iranian macro targeting for self-sufficiency in staples (wheat, barley, maize and rice), this study seeks to answer the question: whether the current domestic production could be considered as a reliable strategy for the replacement of imports and lack of national import dependency in the long run or not?

\section{Materials and Methods}

This study conducted an economic analysis of virtual imports for cereal group (as the most important country's import basket) during the period 1961 to 2013, an analysis of various development plans and its relation to country's water resources. The average amount of virtual water, a product (in this study crop) could be proportionally calculated from the average water requirement to the average yield of the product [10]:

$$
V W C_{c, j}=\frac{\overline{C W R}_{c, j}}{\bar{Y}_{c, j}}
$$

Where $V W C_{c, j}$ is the amount of water used to produce one ton of product $\mathrm{c}$ in year $\mathrm{j}$ in terms of $\left(m^{3} t^{-1}\right)$ and $\bar{Y}_{c, j}$ is the average yield of product $\mathrm{c}$ in cereal group in $\mathrm{j}$ year in terms of (ton $h a^{-1}$ ) and $\overline{C W R}_{c, j}$ is the amount of water used for one hectare of the product in terms of $\left(m^{3} h a^{-1}\right)$. The average cereal yield was calculated using a weighted average for the whole country. Virtual water trade for each product of cereal including import is calculated by multiplying the quantitative amount of import or export of the product in the related virtual water:

$$
V W I_{c, j}=V W C_{c, j} \times I_{c, j}
$$


$V W I_{c, j}$ is the virtual water import for product c (of cereal) in year $\mathrm{j}$ in terms of $\left(\mathrm{m}^{3} y^{-1}\right)$ and $I_{c, j}$ is based on the value of annual imports of the product $\mathrm{c}$ in year $\mathrm{j}\left(\mathrm{m}^{3} \mathrm{y}^{-1}\right)$. The total import of virtual water (TVWI) for the country was calculated as follows:

$$
T V W I_{j}=\sum_{c=1}^{M}\left(V W I_{c, j}\right)
$$

In equation (3), $T V W I_{j}$ is the total import of virtual water in year $\mathrm{j}, \mathrm{M}$ is the number of products imported from the cereal group. Thus, the contribution of each product of cereal will be calculated from the following formula:

$$
\begin{gathered}
S_{W}=\frac{V W I_{W, j}}{T V W I_{j}} \times 100 \\
S_{B}=\frac{V W I_{B, j}}{T V W I_{j}} \times 100 \\
S_{M}=\frac{V W I_{M, j}}{T V W I_{j}} \times 100 \\
S_{R}=\frac{V W I_{R, j}}{T V W I_{j}} \times 100
\end{gathered}
$$

Where $S_{W}, S_{B}$,represent a share of imported virtual water for wheat, barley, maize $S_{R}$ and $S_{M}$ and rice crops from the virtual water of whole cereal, respectively and $V W I_{W, j}$, and $V W I_{M, j}, V W I_{B, j}$ $V W I_{R, j}$ are the imported virtual water for wheat, barley, maize and rice, respectively. Next, we consider the amount of imported virtual water in Iran for any of the products in cereal (wheat, barley, maize and rice) during the period 1961-2013 and the total amount of imported virtual water for the cereal group in the same period as well as the share of each product will be estimated. This analysis is separately presented according to different development plans and finally the relationship between water resources restrictions and the imported virtual water is discussed. The information contained in this study have been extracted from Food and Agricultural Organization (FAO) [4] for cereal imports during the period 1961-2013 and report on water resources in the organization.

\section{Results}

Results of the survey and estimate the amount of virtual water imports products from cereal group over the past 53 years shows that the main contribution has been associated virtual water import wheat imports to the country. So on average about $60 \%$ of virtual water imports in strategic goods related to import wheat during the past 53 years. As the results of this table shows, imports of virtual water has been rising in all four major cereal product. In the case of wheat, wheat selfsufficiency by the year 2004 and the beginning of the celebration, the virtual water imports were reduced and the process went on for years, But the lack of real self-sufficiency in wheat production and lack of attention to efficiency in the production of this product, Imports of wheat and consequently the virtual water import continued again. In the case of barley, imported the greatest volatility and consequently the maximum swing virtual water import happened during the past 53 years. Finally in 2013, the import of virtual water import wheat, rice, corn and barley were respectively 8.02, 3.65, 4.89 and 1.09 billion cubic meters. 
4 of 11

Table 1. Virtual water imports for cereal group and share of them during 1961-2013

\begin{tabular}{|c|c|c|c|c|c|c|c|c|}
\hline \multirow[b]{2}{*}{ Year } & \multicolumn{2}{|c|}{ Wheat } & \multicolumn{2}{|c|}{ Rice } & \multicolumn{2}{|c|}{ Maize } & \multicolumn{2}{|c|}{ Barley } \\
\hline & $\begin{array}{l}\text { Cubic } \\
\text { meter }\end{array}$ & Percent & $\begin{array}{l}\text { Cubic } \\
\text { meter }\end{array}$ & Percent & $\begin{array}{l}\text { Cubic } \\
\text { meter }\end{array}$ & Percent & $\begin{array}{l}\text { Cubic } \\
\text { meter }\end{array}$ & Percent \\
\hline 1961 & 25267410 & 89.1 & 18873113 & 6.7 & 12097800 & 4.3 & 0 & 0 \\
\hline 1962 & 72166500 & 60.8 & 32133311 & 27.1 & 7332000 & 6.2 & 7115000 & 6 \\
\hline 1963 & 11290860 & 81.5 & 11217465 & 8.1 & 7332000 & 5.3 & 7115000 & 5.1 \\
\hline 1964 & 25121250 & 95.9 & 5064171 & 1.9 & 4399200 & 1.7 & 1283546 & 0.5 \\
\hline 1965 & 92315752 & 92.1 & 68766992 & 6.9 & 2901028 & 0.3 & 7618742 & 0.8 \\
\hline 1966 & 28241400 & 85 & 47742401 & 14.4 & 58656 & 0 & 2047697 & 0.6 \\
\hline 1967 & 11291773 & 80.2 & 17042851 & 12.1 & 10910016 & 7.7 & 0 & 0 \\
\hline 1968 & 97688776 & 88.5 & 40730858 & 3.7 & 86260980 & 7.8 & 0 & 0 \\
\hline 1969 & 913500 & 22.3 & 3056571 & 74.7 & 122200 & 3 & 0 & 0 \\
\hline 1970 & 41361453 & 63.6 & 9412298 & 14.5 & 14142206 & 21.7 & 140877 & 0.2 \\
\hline 1971 & 18149253 & 80.1 & 101199770 & 4.5 & 76304124 & 3.4 & 273019626 & 12.1 \\
\hline 1972 & 14092052 & 83.8 & 153701856 & 9.1 & 86102120 & 5.1 & 32935335 & 2 \\
\hline 1973 & 14338460 & 81.2 & 19559043 & 1.1 & 159847376 & 9.1 & 153006652 & 8.7 \\
\hline 1974 & 26197389 & 75.6 & 320307561 & 9.2 & 272424126 & 7.9 & 253981309 & 7.3 \\
\hline 1975 & 26301930 & 75.3 & 478727277 & 13.7 & 95212130 & 2.7 & 290098472 & 8.3 \\
\hline 1976 & 74124130 & 42.4 & 435043574 & 24.9 & 260933660 & 14.9 & 312752632 & 17.9 \\
\hline 1977 & 21179735 & 52.9 & 986909392 & 24.7 & 420393662 & 10.5 & 475005938 & 11.9 \\
\hline 1978 & 13343074 & 48.7 & 454087333 & 16.6 & 471770208 & 17.2 & 480078933 & 17.5 \\
\hline 1979 & 73128598 & 31.5 & 561452108 & 24.2 & 853189402 & 36.8 & 174815550 & 7.5 \\
\hline 1980 & 24299100 & 55.4 & 610245153 & 13.9 & 790665772 & 18 & 552102655 & 12.6 \\
\hline 1981 & 29213857 & 52.6 & 900522364 & 16.2 & 106243735 & 19.1 & 671653154 & 12.1 \\
\hline 1982 & 32326499 & 61.5 & 650520955 & 12.4 & 796544814 & 15.2 & 573301086 & 10.9 \\
\hline 1983 & 43479073 & 60.8 & 936135515 & 13.1 & 119680358 & 16.7 & 669838829 & 9.4 \\
\hline 1984 & 47574002 & 63.3 & 900828523 & 12 & 874361774 & 11.6 & 979190491 & 13 \\
\hline 1985 & 39171939 & 58.8 & 823967557 & 12.4 & 116280143 & 17.5 & 757881262 & 11.4 \\
\hline 1986 & 34863234 & 62.7 & 719140723 & 12.9 & 114104738 & 20.5 & 211840587 & 3.8 \\
\hline 1987 & 58374623 & 69.7 & 122297471 & 14.6 & 109012664 & 13 & 227852183 & 2.7 \\
\hline 1988 & 42263095 & 80.7 & 315638218 & 6 & 568503728 & 10.9 & 126759417 & 2.4 \\
\hline 1989 & 94621371 & 72 & 132859789 & 10.1 & 130054893 & 9.9 & 105788381 & 8 \\
\hline 1990 & 61785723 & 68 & 933534000 & 10.3 & 114357448 & 12.6 & 835522988 & 9.2 \\
\hline 1991 & 66440006 & 71 & 960777132 & 10.3 & 148822247 & 15.9 & 259158183 & 2.8 \\
\hline 1992 & 44821224 & 60 & 142113486 & 19 & 141382833 & 18.9 & 157119122 & 2.1 \\
\hline 1993 & 44752712 & 58.9 & 174436850 & 23 & 937948544 & 12.4 & 435082250 & 5.7 \\
\hline 1994 & 42451806 & 61.6 & 725071508 & 10.5 & 938884596 & 13.6 & 987078180 & 14.3 \\
\hline 1995 & 56637000 & 55.3 & 245880810 & 24 & 140530000 & 13.7 & 711500000 & 6.9 \\
\hline
\end{tabular}


Table 1. Cont.

\begin{tabular}{|c|c|c|c|c|c|c|c|c|}
\hline \multirow[b]{2}{*}{ Year } & \multicolumn{2}{|c|}{ Wheat } & \multicolumn{2}{|c|}{ Rice } & \multicolumn{2}{|c|}{ Maize } & \multicolumn{2}{|c|}{ Barley } \\
\hline & $\begin{array}{l}\text { Cubic } \\
\text { meter }\end{array}$ & Percent & $\begin{array}{l}\text { Cubic } \\
\text { meter }\end{array}$ & Percent & $\begin{array}{l}\text { Cubic } \\
\text { meter }\end{array}$ & Percent & $\begin{array}{l}\text { Cubic } \\
\text { meter }\end{array}$ & Percent \\
\hline 1996 & 70777980 & 71.3 & 173155500 & 17.4 & 108635800 & 10.9 & 3667950 & 0.4 \\
\hline 1997 & 10855938 & 79.1 & 959880404 & 7 & 184525421 & 13.5 & 5469750 & 0.4 \\
\hline 1998 & 64588579 & 73.3 & 950536699 & 10.8 & 984946664 & 11.2 & 4129125 & 4.7 \\
\hline 1999 & 11246895 & 77 & 128285640 & 8.8 & 123082528 & 8.4 & 8450978 & 5.8 \\
\hline 2000 & 12017781 & 73 & 170064130 & 10.3 & 144280562 & 8.8 & 1291193 & 7.8 \\
\hline 2001 & 11763961 & 72 & 117198836 & 7.2 & 207170914 & 12.7 & 1336692 & 8.2 \\
\hline 2002 & 75308629 & 69.1 & 145380521 & 13.3 & 161994674 & 14.9 & 2903788 & 2.7 \\
\hline 2003 & 21081296 & 28.2 & 158220461 & 21.2 & 377565128 & 50.5 & 9070202 & 0.1 \\
\hline 2004 & 40620969 & 7.2 & 164698150 & 29.2 & 215559700 & 38.2 & 1440905 & 25.5 \\
\hline 2005 & 21294233 & 3.3 & 194550660 & 30.1 & 273869018 & 42.4 & 1557890 & 24.1 \\
\hline 2006 & 20096342 & 26.3 & 209036832 & 27.4 & 314994451 & 41.3 & 3846824 & 5 \\
\hline 2007 & 45749176 & 7.6 & 168874125 & 28.1 & 345235651 & 57.5 & 4056773 & 6.8 \\
\hline 2008 & 68201964 & 48.9 & 200615285 & 14.4 & 365496778 & 26.2 & 1472574 & 10.6 \\
\hline 2009 & 99758182 & 56.7 & 134316637 & 7.6 & 456417611 & 26 & 1703109 & 9.7 \\
\hline 2010 & 25691219 & 20.9 & 189420238 & 15.4 & 707539710 & 57.5 & 7661816 & 6.2 \\
\hline 2011 & 12972613 & 1.7 & 188312210 & 24.7 & 445377940 & 58.4 & 1154987 & 15.2 \\
\hline 2012 & 99487658 & 50.7 & 171669374 & 8.8 & 571435183 & 29.1 & 2233954 & 11.4 \\
\hline 2013 & 80176817 & 45.4 & 364735247 & 20.7 & 489469900 & 27.7 & 1094432 & 6.2 \\
\hline
\end{tabular}

If the performance of five-year development plans in Iran to be investigated, it is known that on the average, the highest virtual water imports belonged to wheat equivalent to 26.8 billion cubic meters during the second development plan and it is clear that due to a temporary increase in wheat production, the amount of virtual water imports declined during this period in the fourth development plan and reached about 3.9 billion cubic meters. However, with the lack of continuity of wheat self-sufficiency, virtual water imports have again increased significantly and increased to more than 6 billion cubic meters during the first three years of the fifth development plan. As can be seen, the highest virtual water import fluctuations occurred in the fourth development plan and is indicative of the lack of stability in production and imported strategy of wheat and then, the process is also continued during the three years of the fifth development plan and virtual water import fluctuations are remarkable in it. 
6 of 11

Table 2. The virtual water imports due to wheat imports during the different Development Plans

\begin{tabular}{|c|c|c|c|c|c|}
\hline plans & Minimum & Maximum & Average & $\begin{array}{l}\text { Standard } \\
\text { deviation }\end{array}$ & $\begin{array}{c}\text { Coefficient of } \\
\text { variation }\end{array}$ \\
\hline First development plan & 4475271213 & 9462137139 & 6248420753 & 2046533909 & 0.328 \\
\hline $\begin{array}{l}\text { Second development } \\
\text { plan }\end{array}$ & 5663700000 & 11246895072 & 8260637994 & 2600140742 & 0.315 \\
\hline Third development plan & 406209699 & 12017781279 & 6765389039 & 5368624820 & 0.794 \\
\hline $\begin{array}{l}\text { Fourth development } \\
\text { plan }\end{array}$ & 212942331 & 9975818286 & 3895216618 & 4314560838 & 1.108 \\
\hline Fifth development plan ${ }^{1}$ & 129726135 & 9948765897 & 6032057913 & 5201962308 & 0.862 \\
\hline
\end{tabular}

${ }^{1}$ Fifth development plan is available from 2011 to 2013 (3 years)

As it is shown in Table 3, the highest imported virtual water from barley import has been realized during the during the three years of the fifth development plan amounted to about 1.5 billion cubic meters, whereas the lowest virtual water import fluctuation from barely occurred during this period. The highest imported virtual water fluctuation regarding the import of this crop was also occurred during the second development plan and also in the same year, with lower imports of barley, the lowest virtual water import from the barley also occurred.

Table 3. The virtual water imports due to barley imports during the different Development Plans

\begin{tabular}{cccccc}
\hline Plans & Minimum & Maximum & Average & $\begin{array}{c}\text { Standard } \\
\text { deviation }\end{array}$ & $\begin{array}{c}\text { Coefficient of } \\
\text { variation }\end{array}$ \\
\hline $\begin{array}{c}\text { First development plan } \\
\text { Second development }\end{array}$ & 157119122 & 1057883814 & 548953271 & 384582339 & 0.701 \\
plan & 36679500 & 845097825 & 412177465 & 369393153 & 0.896 \\
$\begin{array}{c}\text { Third development plan } \\
\text { Fourth development }\end{array}$ & 9070202 & 1440905609 & 873648059 & 670491066 & 0.767 \\
$\begin{array}{c}\text { plan } \\
\text { Fifth development plan }\end{array}$ & 1094432146 & 2233954893 & 1494458317 & 641138160 & 0.429 \\
\hline
\end{tabular}

${ }^{1}$ Fifth development plan is available from 2011 to 2013 (3 years)

Regarding the maize, as shown in table 4, the virtual water import of maize imports in the country has been quite rising during different development plans, so that in the first development plan, on average 1.26 billion cubic meters of virtual water import was due to maize import and, this figure has been increased by more than 5 billion cubic meters during the fifth development plan. Meanwhile, the lowest fluctuation in the virtual water imports of maize imports has also been achieved in the same year and the highest fluctuation in the virtual water imports of maize imports also occurred during the third development plan. 
Table 4. The virtual water imports due to maize imports during the different Development Plans

\begin{tabular}{cccccc}
\hline Plans & Minimum & Maximum & Average & $\begin{array}{c}\text { Standard } \\
\text { deviation }\end{array}$ & $\begin{array}{c}\text { Coefficient of } \\
\text { variation }\end{array}$ \\
\hline $\begin{array}{c}\text { First development plan } \\
\text { Second development }\end{array}$ & 937948544 & 1488222476 & 1256824556 & 220575665 & 0.176 \\
plan & 984946664 & 1845254216 & 1310536833 & 338201780 & 0.258 \\
$\begin{array}{c}\text { Third development plan } \\
\text { Fourth development }\end{array}$ & 1442805624 & 3775651282 & 2213141960 & 923315856 & 0.417 \\
$\begin{array}{c}\text { plan } \\
\text { Fifth development plan }{ }^{1}\end{array}$ & 4453779408 & 5714351838 & 5020943417 & 639698329 & 0.127 \\
\hline
\end{tabular}

${ }^{1}$ Fifth development plan is available from 2011 to 2013 (3 years)

The results in table 5 show that regarding the rice, on average, the highest virtual water imports have been realized during the three years of the fifth development plan more than 4.2 billion cubic meters and generally, on average, the ascending trend in the rice virtual water import is completely obvious in various development plans. Additionally, the highest virtual water import fluctuation occurred in the fifth development plan.

Table 5. The virtual water imports due to rice imports during the different development plans

\begin{tabular}{cccccc}
\hline Plans & Minimum & Maximum & Average & $\begin{array}{c}\text { Standard } \\
\text { deviation }\end{array}$ & $\begin{array}{c}\text { Coefficient of } \\
\text { variation }\end{array}$ \\
\hline $\begin{array}{c}\text { First development plan } \\
\text { Second development } \\
\text { plan }\end{array}$ & 933534000 & 1744368507 & 1277682480 & 339055301.9 & 0.265 \\
$\begin{array}{c}\text { Third development plan } \\
\text { Fourth development }\end{array}$ & 1171988363 & 1700641306 & 1511124201 & 210787184.4 & 0.139 \\
$\begin{array}{c}\text { plan } \\
\text { Fifth development plan }\end{array}$ & 1343166377 & 2090368329 & 1814787085 & 303301465.5 & 0.167 \\
\hline
\end{tabular}

${ }^{1}$ Fifth development plan is available from 2011 to 2013 (3 years)

As indicated in Table 6, the total imports of virtual water has been rising in the main cereal during the years 1961 to 2013. As in 1961, the total import of virtual water in imported wheat, barley, maize and rice was equivalent to $0.28 \%$ billion cubic meters, but the amount of virtual water imports was reached to 17.65 billion cubic meters in 2013. This figure was the highest amount of virtual water import from the main cereal group import over the past 53 years. 
8 of 11

Table 6. The total amount of virtual water imports due to cereal group imports in Iran during 1961-2013

\begin{tabular}{|c|c|c|c|}
\hline Year & Cubic meter & Year & Cubic meter \\
\hline 1961 & 283645013 & 1988 & 5237210940 \\
\hline 1962 & 118746811 & 1989 & 13149167784 \\
\hline 1963 & 138573065 & 1990 & 9091203823 \\
\hline 1964 & 261959417 & 1991 & 9352158392 \\
\hline 1965 & 1002444284 & 1992 & 7474204792 \\
\hline 1966 & 332262760 & 1993 & 7592670514 \\
\hline 1967 & 140870602 & 1994 & 6896214944 \\
\hline 1968 & 1103879603 & 1995 & 10239308100 \\
\hline 1969 & 4092271 & 1996 & 9932390500 \\
\hline 1970 & 65056834 & 1997 & 13715771116 \\
\hline 1971 & 2265448877 & 1998 & 8807253765 \\
\hline 1972 & 1681944605 & 1999 & 14605674581 \\
\hline 1973 & 1766259114 & 2000 & 16452421684 \\
\hline 1974 & 3466451950 & 2001 & 16344351363 \\
\hline 1975 & 3494230927 & 2002 & 10894993701 \\
\hline 1976 & 1749971171 & 2003 & 7475055726 \\
\hline 1977 & 4000282493 & 2004 & 5649693814 \\
\hline 1978 & 2740243903 & 2005 & 6455029563 \\
\hline 1979 & 2320743042 & 2006 & 7634629505 \\
\hline 1980 & 4382923580 & 2007 & 6004266915 \\
\hline 1981 & 5555998657 & 2008 & 13953891594 \\
\hline 1982 & 5253016807 & 2009 & 17586269785 \\
\hline 1983 & 7150685315 & 2010 & 12304903035 \\
\hline 1984 & 7511780995 & 2011 & 7621615562 \\
\hline 1985 & 6661844217 & 2012 & 19613766369 \\
\hline 1986 & 5558352119 & 2013 & 17654165328 \\
\hline 1987 & 8378415858 & & \\
\hline
\end{tabular}

Now the main question is whether cereal group imports with the current situation can be controlled and domestic production can be replaced with it? To better answer this question, it is necessary to examine the country's renewable sources per capita over the past years. In Table 7, the renewable water resources per capita was extracted with cubic meters during the period of 5 years from 1963 after FAO report (2016) [4]. As Table 7 shows, renewable water resources per capita is equivalent to 5026 cubic meters in the period 1963 to 1967, that this figure was reduced to 1779 cubic meters in the period 2008 to 2012. The estimate of long-run elasticity for the relationship between renewable water resources per capita and the virtual water import for cereal also showed that with a one percent reduction in the country's renewable water resources, the import of virtual water in the main group cereal will be increased equivalent to 2.89 percent. 
Table 7. Long-run relationship between limited renewable water resources per capita and the virtual

\begin{tabular}{lcc}
\multicolumn{3}{c}{ water import } \\
Period & $\begin{array}{c}\text { Renewable water resources per } \\
\text { capita - Cubic meter }\end{array}$ & $\begin{array}{c}\text { Virtual water import of cereals- } \\
\text { Billion cubic meter }\end{array}$ \\
\hline $1963-1967$ & 5206 & 0.375 \\
$1968-1972$ & 4555 & 1.024 \\
$1973-1977$ & 3935 & 2.895 \\
$1978-1982$ & 3273 & 4.051 \\
$1983-1987$ & 2678 & 7.052 \\
$1988-1992$ & 2357 & 9.861 \\
$1993-1997$ & 2195 & 9.675 \\
$1996-2002$ & 2024 & 13.421 \\
$2003-2007$ & 1910 & 6.644 \\
$2008-2012$ & 1799 & 14.216 \\
\hline
\end{tabular}

But there is a very noticeable point in Figure 1. The relationship between renewable water resources per capita and the virtual water import for cereal group was negative and the determination coefficient of 90 percent confirms the negative correlation identified. Due to this negative relationship and also given that the renewable water resources per capita in the country is increasingly falling, it cannot be expected that domestic production could compensate for the imports of the cereal group and virtual water imports with current technology and without additional harm to water resources.

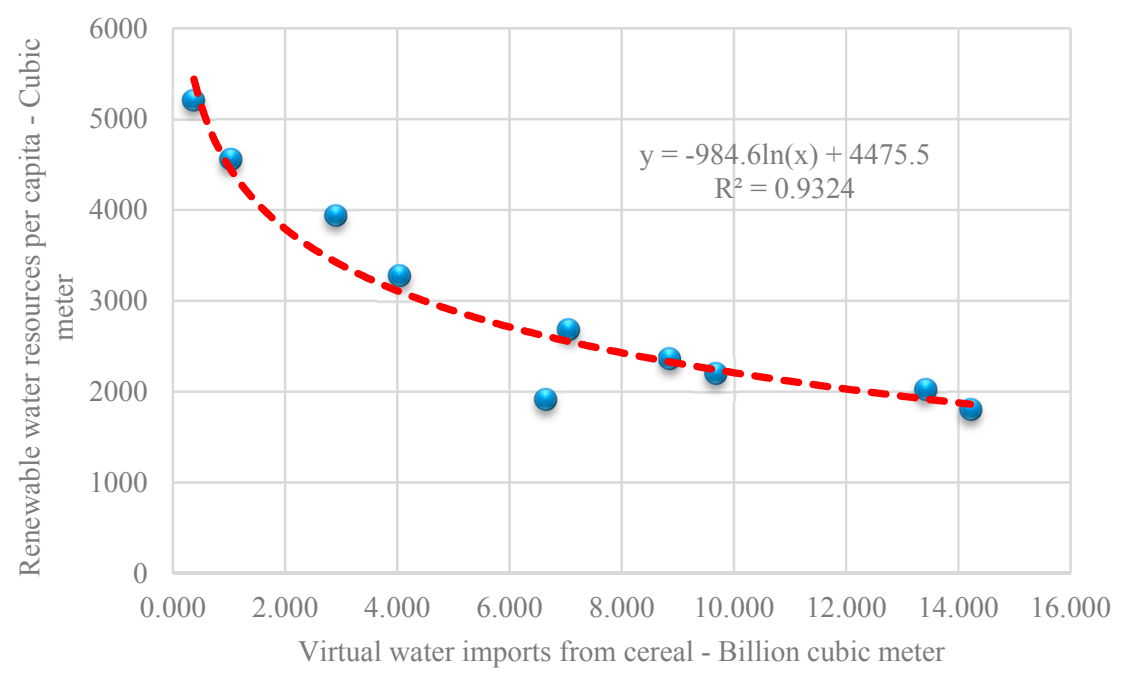

Figure 1.The relationship between renewable water per capita and the amount of virtual water imports

In fact, according to the results of this study, the major cereal group imports is equivalent to more than 17.65 billion cubic meters of virtual water imports in 2013. Given that the current state of the agricultural sector has always been faced with serious challenges and it is demonstrated that this sector consumes about 80 billion cubic meters of water resources, so how can we hope to replace 
surplus of 17.65 billion cubic meters with the use of the country's current irrigation technology, only in the group cereal import?

Replacement of imports with domestic production is not practically feasible without achieving production efficiency and productivity, especially without access to water and improving irrigation efficiency in various sectors of agriculture. If we insist on doing it, it will lead to loss of water resources and creates a critical situation in the future of country's water resources. With the loss of the country's water resources, not also all economic sectors will be practically affected, but also the agricultural sector will face a considerable drop in production and the need to import. So if we follow import purposes according to the plan, it could be helpful in the transition period in which the country seeks to build infrastructure to improve efficiency in domestic production, and after the improvement of productivity in the transition period, we can hope for targeted replacement of imports with domestic production.

\section{Conclusions}

As the results of this study in different parts showed, import of basic goods in Iran has always been increased with the virtual water import in periods of limited water resources. In fact, the agricultural sector in Iran has been accused of excessive water consumption and 90 percent of water resources are used in this section. However, according to general agricultural policies issued in 2012, achieving self-sufficiency and focus on domestic products have been considered as an important goal. Iranian MPs have also required the government to provide food security as well as attain selfsufficiency in basic agricultural products, livestock and aquatic to 95 percent by the end of 2021. But the fact is that with the current trend of water use in agriculture, there is no possibility of increasing the annual consumption more than 17 billion cubic meters of water in excess of current expenditure in the agricultural sector (according to the estimates of virtual water in 2013). Therefore, before the adoption of any policy aimed at achieving self-sufficiency in basic products, it is necessary to provide the necessary infrastructure in order to increase productivity and water resources efficiency. Without improving the productivity and efficiency of water resources in the current situation, achieving the goals of self-sufficiency not only will lead to further crisis of water resources, but also self-sufficiency goals will not be achieved. As a result, with the increased water resource crisis, agricultural production will be confronted with serious harm and in the long term, the country will need to import even more than before and self-sufficiency coefficients will also be reduced. The policy recommendation is that before any hasty adoption of the goals of self-sufficiency programs in agriculture, critical infrastructure should be developed by a group of specialists and experts and the necessary requirements should be provided in order to prevent conflict in the country's policy objectives.

Acknowledgments: This study is the result of national research project in Iran. Thanks to the Chamber of Commerce, Industries, Mines and Agriculture because of the financial support and also thanks to M. H. Shariatmadar, the head of National Center of Strategic Studies of Agriculture and Water and A. Keshavarz, deputy Minister of Agriculture, because of their helpful comments to enhance the results in this study.

Author Contributions: Hamed Rafiee was the leader of the project but the manuscript was written jointly by Hamed Rafiee and Fereshteh balovi. All the results have been conducted with the cooperation of both the authors such as virtual water calculation and investigation of relationship self-sufficiency and limitation of water resources. 
11 of 11

\section{References}

1. Allan, J.A. Virtual water: a long term solution for water short Middle Eastern economies. Occasional paper, Water Issues Group, School of Orient and Affair Student, King's College, London, U.K, 1997.

2. Allan, J.A. Virtual water - the water, food, and trade nexus useful concept of misleading metaphor. J.Water International. 2003, 28, 106-113.

3. Chapagain, A. K.; Hoekstra, A. Y.; Savenije, H. G. Water saving through international trade of agricultural products. J. Hydrol. Earth Syst. Sci.2005, 2, 2219-2251.

4. FAO, http://www.fao.org/faostat/en/. 2016.

5. Fraiture, C.; Cai, X.; Amarasinghe, U.; Rosegrant, M.; Molden, D. Does international cereal trade save water? The impact of virtual water trade on global water use. Comprehensive Assessment Research Report 4. International Water Management Institute. Colombo, Sri Lanka. 2004.

6. Hoekstra, A.Y.; Hung, P.Q. Virtual water trade: a quantification of virtual water flows between nations in relation to international crop trade. Value of Water Research. Report Series No. 11. Delft, the Netherlands, IHE. London. 2002.

7. Safi, R.; Mirlotfi, S. M. Evaluation of sugarcane in Khuzestan province from the perspective of virtual water. J. Water Resources Engineering. 2015, 8, 87-95.

8. Serrano, A.; Guan, D.; Duarte, R.; Paavola, J. Virtual Water Flows in the EU27: A Consumption-Based Approach. J. Industrial Ecology. 2016, 20, 547-558.

9. Silva, V. P. R.; Oliveira, S. D.; Hoekstra, A. Y.; Neto, J. D.; Campos, J. H. B. C.; Braga, C. C.; Araujo, L. E.; Aleixo, D. O.; Brito, J. I. B.; Souza, M. D.; Holanda, R. M. Water Footprint and Virtual Water Trade of Brazil. J. Water. 2016, 8, 1-12.

10. Temea, S.; Allamano, P.; Carr, J. A.; Claps, P.; Laio, F.; Ridolf, F. Local and global perspectives on the virtual water trade. Hydrol. Earth Syst. Sci. 2013, 17, 1205-1215.

11. Yang, H.; Zehnder, A. Virtual water: an unfolding concept in integrated water resources management. J. Water Resources Research. 2007, 43, 1-10. 